\title{
Problematika Pendidikan Anak Pasca Perceraian Orangtua
}

Despi Trianti ${ }^{1}$, Nuzuar ${ }^{2}$, Siswanto $^{3}$, Idi Warsah ${ }^{* 4}$, Endang ${ }^{5}$

1,3Program Studi Pendidikan Agama Islam, Institut Agama Islam Negeri (IAIN) Curup, Bengkulu, Indonesia, 2,4Program Studi Magister Manajemen Pendidikan Islam, Institut Agama Islam Negeri (IAIN) Curup, Bengkulu, Indonesia, ${ }^{5}$ Program Studi Tadris Bahasa Indonesia, Institut Agama Islam Negeri (IAIN) Curup, Bengkulu, Indonesia.

*)4 Corresponding author, $\triangleq i d i w a r s a h @ i a i n c u r u p . a c . i d$

\begin{tabular}{ccc}
\hline Received: & Accepted: & Published: \\
10 July 2020 & 02 November 2020 & 29 December 2020 \\
\hline
\end{tabular}

Abstract

Children are the mandate from Allah in that children have the rights to live and be loved by parents. Children's growth and development are very dependent upon how parents educate and guide them. Children are like white paper given the potential by Allah, and such potential must be developed by parents in any condition and situation even though, for instance in a particular case, the parents must get divorce. Departing from this argument, this study aimed to find out a depiction of children's (17 children) education continuity after their parents got divorce in Babakan Baru Village, Bermani Ulu Raya District, Rejang Lebong Regency, Bengkulu. This study used a qualitative approach with key informants referring to parents who got divorce, close family members, child victims of divorce, and community and religious leaders. In addition, the marriage registrars of KUA in Bernani Ulu Raya were involved as the secondary informants. The data were obtained from observations and interviews, and they were analyzed using the approach of Miles et al with the stages encompassing data reduction, data presentation, and drawing conclusion. This study found the conclusion that the continuity of children's education after parental divorce in Babakan Baru Village was not solely grounded in parental divorce, but it was more dominantly influenced by economic factors and parents' awareness of the importance of children's education.

Keywords: Problematic, Children's Education, Parental Divorce

\begin{abstract}
Absrak
Anak adalah amanah Allah yang mempunyai hak untuk hidup dan memperoleh kasih sayang dari orang tua. Tumbuh kembang anak sangat tergantung pada bagaimana orang tua mendidik dan membimbing mereka. Anak bagaikan kertas putih yang diberi potensi oleh Allah dan harus dikembangkan oleh orang tua dalam kondisi dan situasi apapun termasuk permasalahan yang ditimbulkan dari terputusnya tali perkawinan orang tua. Berangkat dari argumentasi ini penelitian ini bertujuan menemukan gambaran tentang keberlangsungan pendidikan anak (17 Orang) di Desa Babakan Baru Kecamatan Bermani Ulu Raya Kabupaten Rejang Lebong, Bengkulu, pasca perceraian orang tua mereka. Penelitian ini menggunakan pendekatan kualitatif dengan informan kunci orang tua yang melakukan perceraian, keluarga dekat, anak korban perceraian, tokoh masyarakat dan tokoh agama serta pegawai pencatat nikah KUA Bermani Ulu Raya sebagai informan sekunder. Data diperoleh dari hasil observasi dan wawancara dan dianalisis menggunakan pendekatan Miles dkk dengan tahapan reduksi data, penyajian data dan penarikan kesimpulan. Penelitian ini menemukan kesimpulan bahwa keberlangsungan pendidikan anak pasca perceraian orang tua di Desa Babakan Baru tidak semata-mata dilatarbelakangi oleh perceraian orang tua namun yang lebih dominan adalah faktor ekonomi dan kesadaran orang tua tentang pentingnya pendidikan bagi anak-anak mereka. Kata Kunci: Problematika, Pendidikan Anak, Perceraian Orangtua
\end{abstract}

How to Cite: Trianti, D., Nuzuar, N., Siswanto, S., Warsah, I., \& Endang, E. (2020). Problematika Pendidikan Anak Pasca Perceraian Orangtua. ENLIGHTEN: Jurnal Bimbingan Konseling Islam, 3(2), 106-121. https://doi.org/10.32505/enlighten.v3i2.1794 


\section{PENDAHULUAN}

Manusia diciptakan sebagai makhluk sempurna, karena ia diciptakan bukan hanya memiliki nafsu namun juga diberi akal oleh Allah agar dapat mempertahankan keberlangsungan hidup di dunia ini (Afrida, 2018; Azmi \& Zulkifli, 2018; Haderani, 2018). Sinergitas antara nafsu dan akal merupakan keniscayaan bagi manusia jika ingin mendapatkan keberkahan hidupnya. Sebab jika manusia hanya mengedepankan kepentingan nafsu maka ia tidak ada bedanya dengan binatang dan jika ia hanya mengendepankan akalnya maka akan menjadi orang yang angkuh, tidak peka dan tidak memiliki motivasi dalam hidupnya. Freud dalam Warsah menjelaskan bahwa nafsu adalah alam bawah sadar manusia dan dialah yang menjadi penggerak utama dalam pembentukan perilaku setiap manusia. Termasuk di dalamnya menyukai lawan jenis adalah bagian dari hasrat yang dimiliki oleh setiap manusia (Warsah, 2018a). Perasaan suka tersebut akan membawa keberkahan jika dijalankan dengan cara dan aturan yang benar. Dari sisi inilah Islam sangat menganjurkan untuk menikah bagi mereka yang sudah sampai pada usia dewasa.

Anjuran pernikahan dalam agama Islam tersebut tentu bukan hanya bertujuan untuk menyalurkan hawa nafsu lawan jenis secara sah, namun banyak tujuan dari anjuran tersebut, diantaranya memperpanjang keturunan (Asman, 2019; Handayani \& Syafliwar, 2017). Bahkan hal inipun merupakan tujuan utama dalam pernikahan. Namun tidak semua perjalanan rumah tangga berjalan dengan mulus, pasti akan ditemukan masalahmasalah dalam menjalaninya, mulai dari urusan ekonomi sampai pada urusan kesepahaman. Ketika suami istri menjalaninya dengan saling memahami kekurangan masing-masing dan bersabar dalam menghadapi permasalahan yang ditemui tentu masalah tersebut akan teratasi. Jika sikap saling memaafkan atas kesalahan masing-masing tumbuh maka akan menetralisir konflik satu sama lain (Warsah, 2020a). Namun jika rumah tangga tidak mampu menghadapi masalah yang ada secara bersama-sama boleh jadi bahtera rumah tangga akan berakhir dengan perceraian.

Terkait dengan problem rumah tangga, hakikatnya rumah tangga merupakan kantung rahim keluarga, yakni tempat proses tumbuh-kembanganya anak menuju masa depan yang lebih baik. Oleh karena itu tidak bisa dinafikan anak akan mengalami proses tumbuh-kembanganya secara baik dan normal karena faktor kedua orang tua (Gazali, 2018; Hair \& Hair, 2018). Di sini pentingnya peran orang tua dalam menjaga keharmonisan rumah tangga demi menjaga stabilitas psikologi anak. Tetapi sebaliknya, apabila orang tua 
sudah tidak harmonis lagi, bahkan melakukan perceraian, anak akan mengalami guncangan yang dahsyat dan akan berdampak pada perilaku mereka. Sebab, bagaimanapun, anak merupakan sosok duplikasi dari orang tuanya.

Yakin dalam temuan penelitiannya mengatakan bahwa menjadi hal yang dianggap lumrah apabila anak berubah perilakunya dari pribadi yang periang menjadi pemurung, temperamental, kurang percaya diri, dan merasa rendah diri terhadap lingkungannya disebabkan karena perilaku orang tuanya yang sering bertengkar di depan anak-anak hingga menyebabkan perceraian (Al Yakin, 2016)

Inilah dampak utama dari sebuah perceraian. Bahkan berdasarkan hasil penelitian yang dilakukan Hasanah, perceraian orang tua mendorong anak untuk melakukan hal-hal negatif dan bahkan melanggar norma agama dan hukum, seperti seks bebas, penyalahgunaan narkoba, tauran dan lainlain (Hasanah, 2020). Intinya, sepasang suami istri atau ayah-ibu merupakan insan yang memiliki peranan besar dan utama dalam pendidikan anak (Abidin et al., 2018; Daheri \& Warsah, 2019).

Pendidikan pada umumnya ditujukan untuk menanamkan nilai-nilai dan norma-norma tertentu sebagaimana yang telah ditetapkan dalam filsafat pendidikan, yakni nilai atau norma yang dijunjung tinggi oleh suatu lembaga pendidikan (Harisah, 2018; Kusumawati, 2016; Utami, 2018). Menurut Langeveld dalam Lisnasari dan Riadin \& Fitrian pendidikan adalah setiap usaha, pengaruh, perlindungan dan bantuan yang diberikan kepada anak yang bertujuan kepada pendewasaan anak, atau lebih tepat membantu anak agar cukup cakap melaksanakan tugas hidupnya sendiri (Lisnasari, 2017; Riadin \& Fitriani, 2018). Pengertian ini memberikan gambaran bahwa pendidikan anak menuju kedewasaan tersebut memerlukan intervensi dari orang dewasa. Kata dewasa di sini adalah orang tua, guru dan orangorang yang berada di lingkungan di mana anak tersebut tumbuh dan berkembang. Sementara Dewey dalam Gumilar, Kusmira dan Saihu menyatakan bahwa pendidikan adalah proses pembentukan kecakapan-kecakapan fundamental secara intelektual dan emosional agar mampu beradaptasi dengan alam dan sesama manusia (Gumelar, 2017; Kusmira, 2018; Saihu, 2020).

Beberapa pengertian pendidikan yang diberikan para ahli tersebut secara esensial terdapat kesatuan unsur-unsur yang terdapat didalamnya. Pengertian pendidikan tersebut menunjukkan suatu proses bimbingan, tuntunan atau kepemimpinan yang di dalamnya mengandung unsur unsur seperti pendidik, anak didik, tujuan dan sebagainya. Oleh karenanya pendidikan merupakan fenomena manusia yang fundamental, yang juga mempunyai sifat konstruktif dalam hidup manusia. Karena itulah manusia dituntut untuk mampu mengadakan refleksi ilmiah tentang pendidikan tersebut, sebagai pertanggung jawaban terhadap perubahan yang dilakukan, yaitu mendidik dan di didik. 
Dalam arti sederhana, pendidikan merupakan usaha manusia untuk membina kepribadiannya sesuai dengan nilai-nilai di dalam masyarakat dan kebudayaan (Warsah, 2017, 2018b). Dalam konteks perkembangannya, istilah pendidikan berarti memberikan bimbingan atau pertolongan dengan segaja oleh orang dewasa agar ia menjadi dewasa (Wandasari, 2017). Selanjutnya, pendidikan diartikan sebagai usaha yang dijalankan oleh seseorang kepada orang lain agar menjadi dewasa atau mencapai tingkat hidup dan penghidupan yang lebih tinggi.

Pendidikan merupakan proses yang secara terus menerus diberikan kepada anak sampai mereka mencapai pribadi dewasa secara fisik maupun mental. Proses ini berlangsung dalam jangka waktu tertentu. Bila anak didik sudah mencapai kedewasaan, maka ia sepenuhnya mampu bertindak sendiri bagi kesejahteraan hidupnya dan masyarakat. Pendidikan yang dimulai dari keluarga menuntut anak mencapai tujuan-tujuan tertentu dan hal ini tampak pada perubahan-perubahan dalam diri anak (Warsah, 2020b). Perubahan sebagai hasil pendidikan merupakan gejala kedewasaan yang secara terus menerus mengalami peningkatan serta penentuan diri atas tanggung jawab terhadap perilaku mereka di kemudian hari (Warsah, 2018b).

Saat ini kasus rumah tangga menjadi hal yang sangat fenomenal terjadi, hal tersebut dapat kita temui baik dalam dunia nyata maupun di social media, hal tersebut penulis telusuri terkait penelitian ini dengan kasus rumah tangga di wilayah KUA Bermani Ulu Raya. Menurut data dari kantor KUA tersebut ditemukan 119 kasus yang terjadi pada keluarga, diantaranya disebabkan oleh kasus KDRT, perselingkuhan, dan faktor ekonomi (Dokumen KUA Bermani Ulu Raya tahun 2019). Menyoroti fakta yang terjadi di lapangan bahwa kasus perceraian terjadi diakibatkan oleh tidak harmonisnya hubungan keluarga. hal tersebut berdampak ketika anak melihat langsung konflik yang terjadi antara ayah dan ibunya. Ditambah lagi dengan pola pengasuhan orang tuanya berubah, Hal tersebut tentu akan sangat berpengaruh terhadap keadaan psikologis anak. Saat yang bersamaan, pada usia remaja anak membutuhkan tauladan dari kedua orang tuanya yang menjadi tempat untuk ia berpijak dan bertindak. Seorang anak akan meniru kedua orang tuanya. Ia akan lebih mudah terpengaruh oleh contoh-contoh perilaku yang kurang baik dari orang tuanya dibandingkan dengan nasehatnasehat yang diperoleh dari perkembangan dan pertumbuhannya selama usia anak-anak (Daheri \& Warsah, 2019).

Perceraian menjadi kasus yang menarik khususnya di Kecamatan Bermani Ulu Raya karena berdasarkan data statistik yang diperoleh ternyata terjadi peningkatan angka setiap tahun secara berturut-turut terjadi kasus perceraian dan perceraian tersebut yakni cerai talak dan cerai gugat. Kasus ini tentu saja akan memberikan konsekuensi tidak hanya pada kedua belah pihak yaitu suami dan istri saja, tetapi juga memberikan dampak pada anak. Perceraian orang tua yang 
terjadi akan memunculkan permasalahanpermasalahan yang lebih kompleks saat anak berada pada masa awal remaja karena masa ini merupakan masa yang paling sulit bagi anak-anak dari keluarga bercerai. Jika orang tua berpikir tentang dampak yang akan terjadi pada anak tentu mereka akan meninjau ulang keputusan tersebut dan perdamaian merupakan jalan terbaik demi keberlangsungan rumah tangga mereka.

Tidak sedikit anak mengalami permasalahan-permasalahan dari implikasi pengasuhan keluarga bercerai. Mereka kesulitan dalam menghadapi tantangan dan cobaan yang ditemui dalam kehidupan sehari-hari. Namun tidak semua anak terjerumus kedalam situasi negatif tersebut meskipun kondisi orang tuanya mengalami perceraian. Fikri dalam penelitiannya pada anak dan dewasa menyimpulkan bahwa perceraian dapat menjadi pengalaman yang memberikan kesempatan anak untuk mendapatkan kebahagiaan dan menyelamatkan diri dari lingkungan rumah yang disfungsional (Fikri, 2018). Problematika pendidikan anak Pasca perceraian Orang tua menjadi penting karena diakui sangat menentukan bagaimana gaya berpikir dan keberhasilan hidup seseorang. Berangkat dari uraian pendahuluan ini, penelitian ini berusaha menemukan gambaran tentang permasalahan pendidikan anak pasca perceraian orangtua dan studi kasus penelitian ini adalah Desa Babakan Baru Kecamatan Bermani Ulu Raya, Kabupaten Rejang Lebong, Bengkulu.

\section{METODE}

Penelitian ini menggunakan pendekatan kualitatif. Tujuan penelitian ini adalah menemukan gambaran tentang permasalahan pendidikan anak pasca perceraian orang tua di Desa Babakan Baru Bermani Ulu Raya. Informan dalam penelitian ini adalah pelaku perceraian (orang tua), kepala KUA dan pegawai KUA Bermani Ulu Raya dan beberapa masyarakat Desa Babakan Baru. Teknik pengumpulan data dalam penelitian ini melalui Observasi, wawancara langsung dan dokumentasi terkait. Sedangkan analisis data menggunakan teori yang dibangun oleh Miles et.al dengan tahapan sebagai berikut: pengumpulan data dari hasil observasi, wawancara dan dokumentasi (Roulston, 2014), setelah data terkumpul tahapan selanjutnya pemilihan data yang dikelompokkan sesuai dengan domain yang telah ditetapkan dalam deskripsi tujuan masalah lalu diurai dan tahapan terakhir dibuat kesimpuln sebagai jawaban dari masalah yang telah dirumuskan (Helaluddin \& Wijaya, 2019; Miles et al., 2014).

\section{HASIL TEMUAN}

Berdasarkan hasil penulusuran dilapangan, ada beberapa hal yang penulis temukan, diantaranya:

\section{Faktor-faktor yang menyebabkan terjadinya perceraian}

Adapun faktor-faktor penyebab terjadinya perceraian menurut HW warga Desa Babakan Baru adalah sebagai berikut: “Rusaknya komunikasi keluarga; Hilangnya tujuan dan perhatian bersama; Ketidakcocokan dalam seksualitas; 
Ketidaksetiaan atau perselingkuhan; Hilangnya kegairahan dan kesenangan dalam hubungan suami istri; Keuangan atau ekonomi; Pertengkaran masalah anakanak; dan adanya campur tangan dari keluarga dekat seperti ipar/mertua" (Wawancara, 20 Maret 2020).

Sedangkan menurut SR tokoh masyarakat Babakan Baru mengatakan bahwa "biasanya sumber konflik perceraian tersebut tidak dapat dijelaskan oleh kedua belah pihak kecuali dengan alasan bahwa tidak bahagia, tidak sejalan dan merasa ada sesuatu yang menghalangi kebahagiaan tersebut" (Wawancara, 05 Maret 2020). Kondisi seperti ini pada dasarnya kedua pasangan sedang merasakan warna lain dalam kehidupan, tatkala kebahagiaan rumah tangga dirasa mulai mundur maka akan muncul konflik. Konflik ini akan terjadi terus-menerus hingga pada akhirnya akan bermuara pada perceraian.

Selain itu, menurut SY konflik dalam rumah tangganya juga berawal dari kegemaran sang istri aktif di sosial media seperti facebook yang mengakibatkan terjadi komunikasi dengan teman laki-laki, sehingga timbul perasaan lebih dan hubungan yang dekat diantara mereka. Hal ini kemudian yang akan memicu timbulnya konflik antara pasangan suami istri sehingga berujung pada perceraian, sementara mereka telah dikaruniai anak pada usia sekolah dasar (data wawancara, 16 Maret 2020).

Berbeda dengan lainnya ibu muda bernama SS mengatakan bahwa kasus perceraian yang terjadi pada dirinya adalah kerena suami tidak memiliki pekerjaan tetap dan memiliki karakter temperamental segingga tidak jarang SS mendapat perlakuan kekerasan dari sang suami. Meskipun telah dikaruniai anak SS meminta suami untuk menceraikannya. (Wawancara, 16 Maret 2020).

Terlepas dari berbagai alasan pelaku perceraian di atas, dapat disimpukan bahwa faktor utama dari kasus tersebut adalah stabilitas mental dan emosional dari pelaku kurang stabil sehingga keputusan bercerai menjadi solusi terbaik untuk mengatasi persoalan dalam rumah tangga. Jika kematangan emosi telah ada pada diri mereka tentu akan banyak pertimbangan ketika mereka memutuskan untuk melakukan perceraian salah satunya adalah pendidikan anak di masa yang akan datang.

\section{Problematika pendidikan anak pasca perceraian orang tuanya}

Berdasarkan hasil observasi dan wawancara di lokasi penelitian, ditemukan bahwa perceraian orang tua disebabkan oleh enam faktor yaitu faktor ekonomi, perbedaan status sosial, perselingkuhan, tidak mendapat restu orang tua, kekerasan dalam rumah tangga (KDRT), dan menikah diusia dini. Namun terkait dengan pengasuhan anak pascaperceraian orang tua dibantu oleh kerabat dekat. Problem pengasuhan seperti ini (tanpa kerjasasama ayah dan ibu karena perceraian) akan berimplikasi pada perubahan besar dalam hidup anak. Perubahan tersebut membawa dampak negatif apabila tidak ditangani dengan baik. Perkembangan sosial dan 
emosional anak terlihat pada kegiatan sehari-hari anak di sekolah, mulai dari datang ke sekolah hingga anak pulang ke rumah. Anak akan menunjukkan perkembangan negatif, namun jika orang tua dan guru bersinergi mengatasi guncangan yang terjadi dalam diri si anak tentu pengaruh negatif terhadap perkembangan anak tersebut akan dapat diminimalisir.

Menurut salah satu orang tua yang anaknya mengalami kasus perceraian menyatakan bahwa "perceraian orang tua dapat memberikan dampak buruk bagi anak, baik fisik maupun mental. Sehingga perceraian harus dipertimbangkan secara matang, dan orang tua harus bisa memberikan pengertian yang baik kepada anak sehingga dapat mengurangi dan mengatasi dampak buruk akibat perceraian" (Wawancara, 02 April 2020). Namun menurut salah satu pegawai KUA Bermani Ulu Raya, mengatakan bahwa fungsi keluarga untuk memberikan pengertian dan perhatian pada anak ternyata tidak berfungsi dalam kaitannya dengan kasus perceraian (Wawancara, 08 April 2020). Anak beserta keluarga terdekat korban perceraian diharapkan terlibat aktif dalam proses intervensi yang akan dilakukan, supaya mampu mencapai tujuan yang dikehendaki.

Seperti kasus yang dialami korban berinisial SF, SF berkonsultasi dengan pekerja sosial karena mereka dapat memberikan pertolongan sesuai dengan tahapan pertolongan pekerjaan sosial, seperti memberikan layanan konseling keluarga. Upaya tersebut melibatkan berbagai pihak untuk turut serta aktif antara lain klien, keluarga, masyarakat, dan pekerja sosial.

Perceraian memiliki pengaruh terhadap pertumbuhan dan perkembangan anak usia dini terutama berkaitan pada pengelolaan emosi, perilaku sosial serta kesehatan anak. Dampak tersebut dipengaruhi pula oleh sikap orang tua terhadap anak pasca perceraian. Dampak negatif yang timbul dapat diminimalisir dengan mencukupi kebutuhan fisik dan psikis anak. Mengutip teori Maslow, menyebutkan setidaknya ada lima kebutuhan yang harus terpenuhi oleh orang tua terhadap anak yakni kebutuhan fisiologis, kebutuhan akan rasa aman, kebutuhan akan rasa percaya diri, kebutuhan akan rasa memiliki dan cinta, dan kebutuhan aktualisasi diri. Perpisahan suami dan istri tidak berarti perpisahan orang tua bagi anak-anaknya, anak memiliki hak untuk mendapatkan kasih sayang, perhatian, komunikasi serta waktu bersama orang tua mereka.

Perceraian yang terjadi di antara orang tua memiliki dua kemungkinan, yakni bisa jadi sangat berdampak atau tidak begitu berdampak bagi anak. perceraian yang tidak begitu berdampak bagi anak adalah perceraian yang terjadi ketika anaknya masih kecil atau belum mengetahui arti perceraian sehingga mereka sudah terbiasa tumbuh besar hanya dengan satu orang tua saja. Selain itu, peran seorang ibu juga sangat mempengaruhi perilaku anak setelah perceraian. 
Hubungan yang baik antara suami dan istri setelah perceraian juga mempengaruhi perilaku anak. Jika setelah bercerai kedua orang tuanya tetap bahu membahu dalam mendidik anak, tetap memperhatikan sikap keagamaan anak baik dalam aspek ibadah, akhlak, dan lainlain maka anak akan tetap berada dalam pengawasan dan penjagaan orang tua sehingga sangat kecil potensi bagi anak untuk melakukan hal-hal yang tidak baik. Sedangkan perceraian yang berpotensi memiliki dampak negatif adalah perceraian yang terjadi ketika anak sudah besar atau sudah paham apa yang dimaksud dengan perceraian, anak ingin menunjukkan sikap berontak atau tidak terima atas perceraian itu. Karena usia mereka yang masih labil dan belum bisa mengambil sikap yang benar atas ketidakterimaannya, akhirnya mereka melampiaskan pada hal-hal yang negatif seperti mogok ngaji, membantah, membentak, mencuri, dan lain sebagainya. Setelah orang tua bercerai pasti perhatian orang tua berubah. Awalnya mereka bekerjasama membangun rumah tangga mulai dari merawat anak, mencari nafkah untuk anaknya, setelah perceraian semua berubah drastis. Mereka menjadi orang tua tunggal (single parent).

Hal ini sesuai dengan pendapat ibu KS yang menyatakan arti penting kelengkatan orang tua dalam pendidikan anak di rumah yaitu "Peran keluarga yang dijalankan dan dibebani kepada satu orang saja akan menjadi jauh lebih sulit jika dibandingkan dengan dua orang. Perceraian menyebabkan ayah atau ibu menjadi kurang mampu mengatasi kehidupan anaknya sehari-hari". (Wawancara, 14 April 2020). Akibat dari hal tersebut maka muncul serentetan kasus yang sebenarnya tidak perlu terjadi, misalnya soal makan yang dianggap hal yang "sepele", makan tidak pada waktunya, tidur tidak teratur atau anak sering terlambat ke sekolah. Setidaknya itulah yang peneliti temukan di lapangan pada saat observasi ke rumah salah seorang anak yang orang tuanya telah berpisah (Observasi, 14 April 2020).

Peneliti menemukan bahwa anak merasa ketakutan karena kehilangan sosok ayah atau ibu mereka. Takut kehilangan kasih sayang orang tua yang kini tidak tinggal serumah. Dampak perceraian yang dirasakan oleh anak-anak antara lain: sedih, kesepian, dan kecewa. Dampak tersebut tercermin dalam bentuk perilaku: 1) Menjadi kasar, hal tersebut dilakukan semata-mata untuk mencari perhatian dari orang lain; 2) Menjadi pendiam, tidak lagi ceria dan tidak suka bergaul; 3) Lebih mendahulukan kepentingan egonya tanpa memperhatikan keadaan teman-temannya; 4) Bersikap acuh tak acuh terhadap temantemannya; 5) Kurang bisa menjaga hubungan baik dengan teman-temannya; dan 6) Suka melamun terutama menghayalkan orangtuanya akan bersatu lagi (Observasi, 14 April 2020).

Hasil wawancara peneliti dengan anak korban perceraian ketika ditanya tentang keberadaan orang tua mereka ratarata menjawab dengan perasaan malu dan sedih dan mereka berkata bahwa orangtua mereka sudah meninggal atau berada di 
luar kota. Peneliti juga menemukan bahwa relasi anak-anak korban perceraian di sekolah dengan guru-guru juga berbedabeda ada yang baik dan ada yang buruk. Menurut hasil analisis peneliti, perceraian bagi anak adalah "tanda kematian" keutuhan keluarganya, rasanya separuh "diri" anak telah hilang, hidup tak akan sama lagi setelah orang tua mereka bercerai dan mereka harus menerima kesedihan dan perasaan kehilangan yang mendalam. Contohnya, anak harus memendam rasa rindu yang mendalam terhadap ayah/ibunya yang tiba-tiba tidak tinggal bersamanya lagi.

Anak yang orang tuanya bercerai mempunyai masalah terkait emosinya sendiri. Ia merupakan korban dari dua orang tua yang mempunyai problem dan kesulitan yang mereka kira dapat dipecahkan melalui perceraian. Dalam suatu keluarga di mana seorang ayah telah berperilaku jahat sebelum bercerai maka satu dari dua anak akan mengatakan bahwa ia menyerupai ibu dan menyimpulkan bahwa saudaranya menyerupai ayah. Jelaslah bahwa tidak ada seseorang pun yang menyukai gambaran ayah yang malas, tidak berperasaan, suka bertengkar sebagai model yang pantas. Orang tua yang bercerai juga kerap kali tidak dapat fokus dalam mengurus anaknya, karena semakin banyak hal yang perlu diselesaikannya sebagai orangtua tunggal.

Berdasarkan hasil observasi dan wawancara di lokasi penelitian, problematika pendidikan anak pasca orang tua bercerai oleh HM selaku Kadus Desa
Babakan Baru mengatakan :"bapak bersikap acuh tak acuh terhadap anaknya setelah bercerai, sedangkan ibu tetap menyayangi anaknya, sehingga anak-anak banyak yang mengikuti ibu, ibulah yang membiayai hidup dan pendidikannya. Setelah itu ibu menikah lagi anaknya dititipkan ke neneknya (Wawancara, 25 April 2020). Ungkapan di atas sejalan dengan perkataan PR kakek dari bukhori menceritakan setelah orang tuanya bercerai ia tinggal bersama kakeknya. Sedangkan ibunya bekerja banting tulang di Kalimantan, dan ayahnya acuh tak acuh. Ketika bukhori ke rumah ayahnya ia diberikan uang tetapi hal tersebut menyebabkan pertengkaran dengan istri mudanya (Wawancara, 05 Mei 2020).

Terkait dengan apa yang dikatakan di atas, hal tersebut juga terjadi pada SM, ia menceritakan setelah orang tuanya bercerai dia lebih senang tinggal bersama neneknya, sedangkan ayah nya tidak pernah lagi mencarinya, bahkan dia sendiri tidak pernah melihat wajah ayahnya sejak lahir. Hanya ibunya yang tetap menemuinya dan memberikan uang untuk keperluan sekolah" (Wawancara 01 Mei 2020).

Beberapa tanggapan informan di atas adalah testimoni bahwa pasca perceraian orangtua, anak lebih suka mengikuti ibu, setelah ibunya menikah anak-anaknya ditinggalkan di rumah keluarga dekatnya. Hanya saja biaya hidup dan pendidikan tetap kembali menjadi tanggungan ibu. Artinya, perceraian bukanlah salah satu penghambat bagi kelangsungan pendidikan anak tapi yang 
paling menentukan adalah kesadaran tentang pentingnya pendidikan dan faktor ekonomi. Terbukti bahwa pendidikan anak-anak di Desa Babakan Baru, dari hasil wawancara bersama masyarakat dan anakanak yang orang tuanya bercerai teryata jenjang pendidikan mereka berbeda-beda dari jenjang pendidikan yang paling rendah sampai yang paling tinggi. Tetapi kebanyakan anak yang orang tuanya bercerai pendidikanya sampai pendidikan menengah saja seperti pada Tabel 1 .

Tabel. 1: Daftar Nama-nama Anak dengan Orang Tuannya Bercerai dan Jenjang Pendidikanya di Desa Babakan Baru

\begin{tabular}{cccc}
\hline No & $\begin{array}{c}\text { Nama } \\
\text { Anak } \\
\text { (inisial) }\end{array}$ & $\begin{array}{c}\text { Jenjang } \\
\text { Pendidikan }\end{array}$ & Keterangan \\
\hline 1 & NL & SMP & Kelas 3 \\
\hline 2 & AP & SD & Kelas 4 \\
\hline 3 & TN & SMP & Tidak tamat \\
\hline 4 & NV & SD & Kelas 2 \\
\hline 5 & SR & SD & Kelas 5 \\
\hline 6 & TRN & SD & Kelas 3 \\
\hline 7 & YP & SD & Kelas 4 \\
\hline 8 & SM & SMA & Tamat. \\
& & & Tidak \\
& & PT & Semester 3 \\
\hline 9 & SSR & SD & Kelas 3 \\
\hline 10 & AM & SD & Kelas 4 \\
\hline 11 & GS & SMA & Tidak tamat \\
\hline 12 & YA & SMP & Kelas 2 \\
\hline 13 & RL & SD & Kelas 5 \\
\hline 14 & MJ & SD & Kelas 2 \\
\hline 15 & EP & SDP & Tidak tamat \\
\hline 16 & ND & Kelas 4 \\
\hline 17 & NL & & data hasil Observasi, 10 Mei 2020) \\
\hline & & diatkan Tabel 1 data hasi
\end{tabular}

Jika di lihat dari Tabel 1 data hasil observasi dan wawancara bahwa sesungguhnya dalam kasus perceraian yang ada di desa Babakan Baru bahwa perceraian bukanlah faktor dominan bagi terwujudya kelangsungan pendidikan anak. Namun kesadaran orang tua tentang pentingnya pendidikan serta keadaan ekonomi orang tua adalah faktor yang paling utama di temukan di Desa tersebut dalam keberlangsungan pendidikan anak. Meskipun realitas di lapangan, pasca terjadinya perceraian ibu yang lebih banyak dibebani tanggung jawab yang besar dalam pendidikan anak sedangkan ayah kebanyakan menghilang dan tidak peduli lagi tentang pendidikan anak-anak mereka.

Gejala di atas dapat dipahami mengingat bahwa perceraiaan pada umumnya terjadi pada orang tua yang memiliki pendidikan yang rendah, dan kondisi ekonomi yang pas-pasan, sehingga bagi putra putri mereka dalam melangsungkan pendidikannya hanya sampai tingkat menengah saja. Oleh karena itu, apabila anak tidak bisa melangsungkan pendidikannya kejenjang yang lebih tinggi semata-mata bukan akibat dari perceraian saja, tetapi juga disebabkan oleh faktorfaktor lain. Seperti kesadaran orang tua tentang pentingnya pendidikan keadaaan ekonomi orang tua untuk membiayai anak ke jenjang yg lebih tinggi.

Pada dasarnya orang tua sebagai penanggung jawab utama pendidikan anak terkadang tidak dapat melaksanakan fungsi dan tanggung jawab dengan baik. Jika dilihat perceraian bukanlah faktor yang dominan untuk tidak terwujudnya keberlangsungan pendidikan anak karena pada hakikatnya melanjutkan pendidikan yang lebih tinggi dapat memberikan kebanggaan pada orang tua, namun demikian kesadaran dan kondisi ekonomi 
orang tua adalah gejala yang paling utama untuk kelangsungan pendidikan anak. Akan tetapi kelangsungan pendidikan anak juga harus disertai dengan dukungan dan tanggung jawab yang penuh dari orang tua walaupun statusnya sudah bercerai.

Sejalan dengan pendapat tersebut kesadaran akan tanggung jawab orang tua terhadap anaknya dalam hal pendidikan sangat besar pengaruhnya. Walaupun dalam kondisi bercerai orang tua tidak akan lepas dari pendidikan anaknya. Perceraian tidak selamanya membawa masalah yang negatif bagi perkembangan anak-anaknya. Ketika anak-anaknya menginjak dewasa mereka akan mengerti arti dari seluk beluk perceraian asalkan orang tua tetap memperhatikan perkembangan anaknya.

Secara aktual penceraian dan keadaan ekonomi keluarga merupakan dua masalah yang berbeda namun terkait, karena keduanya ibarat dua sisi dari mata uang yang sulit dipisahkan. Boleh jadi kemiskinan menjadi penyebab paling dominan dalam kasus perceraian, akan tetapi satu hal yang harus digarisbawahi adalah, kasus perceraian dalam kondisi ekonomi yang bagaimanapun tetap merupakan suatu masalah yang tidak dapat diabaikan dalam perkembangan anak.

\section{Langkah-langkah yang ditempuh untuk menanggulangi perceraian}

Berdasarkan hasil observasi dan wawancara bersama tokoh masyarakat sekaligus sesepuh Desa Babakan Baru berkenaan dengan sarannya agar meminimalisir tingkat perceraian di Desa tersebut sehingga dikemudian hari tidak ada lagi anak yang menjadi korban karena perceraian orang tua, baik itu korban perasaan maupun pemenuhan hak mereka menerima pendidikan dari orang tuanya. Langkah-langkah tersebut antara lain: Pertama, meminimalisir perselisihan dan pertengkaran dalam keluarga dengan menumbuhkan sikap saling pengertian, tidak mengedepankan ego, menyelesaikan masalah dengan cara diskusi, serta tidak membesar-besarkan masalah.

Kedua, untuk menghindari perselingkuhan dapat dilakukan dengan menumbuhkan niat dan tekat dari kedua belah pihak untuk memperbaiki hubungan perkawinan mereka, niat dan tekat harus dilakukan secara bersama-sama dan mengakui kesalahan yang telah dilakukannya dengan meminta maaf dan tidak akan mengulangi kesalahan tersebut. Ketiga, menjalin komunikasi dengan baik karena komunikasi menjadi salah satu penyebab kehancuran rumah tangga. Komunikasi adalah aspek yang paling penting dalam keluarga, antara suami dan istri harus memelihara keterbukaan agar saling mengerti dan memahami.

Keempat, jika berniat untuk berpisah maka pikirkanlah keberlangsungan masa depan anak-anak, karena anak membutuhkan kedua orang tuanya untuk melangsungkan kehidupan. Hal tersebut dapat menjadi senjata ampuh untuk meredam konflik antara suami-istri. Peneliti juga menemukan satu keluarga yang orang tuanya sudah berpisah namun masih terjalin komunikasi yang intens dari 
pasangan yang bercerai tersebut terutama pada keberlangsungan pendidikan anak mereka. Bagi anak sendiri ini merupakan bukti bahwa orangtua masih saling mencintainya. Satu kasus ini membuktikan bahwa kehadiran orang tua untuk tetap bisa bertemu dengan anak membuat anak percaya bahwa mereka dikasihi.

\section{PEMBAHASAN}

Sebab-sebab perceraian secara teoretis maupun realitas di lapangan telah dipaparkan baik pada kajian pendahuluan maupun paparan data hasil penelitian antara lain:

Pertama, terjadi konflik antara kedua belah pihak, hal itu disebabkan karena suami-istri khususnya pasangan muda berbeda pendapat dan pandangan tentang keberlangsungan hidup. Pertengkaran suami-istri tersebut terjadi karena beberapa hal antara lain: Pemahaman yang keliru tentang rumah tangga; Tidak mau mengalah satu sama lain; Masalah anak; Menyesali pernikahan dengan alasan keliru memilih pasangan dan Ekonomi yang kurang memadai.

Kedua, Perselingkuhan. Pada era sekarang ini hampir tidak ada lagi ruang privat bagi setiap individu, baik di kotakota besar sampai pelosok desa dengan majunya media informasi dan komunikasi. Seluruh lapisan masyarakat sudah sangat familiar dengan sosial media bahkan dengan mudah seseorang dapat mengakses tayangan-tayangan yang menjerumuskan dalam perselingkuhan. Masalah perselingkuhan dapat terjadi di manamana dan kapan saja baik yang berstatus telah berkeluarga atau masih sendiri karena mereka dapat saling mengenal satu sama lain melalui media sosial.

Ketiga kurangnya komunikasi. Komunikasi adalah proses memberikan informasi baik secara lisan maupun tulisan dengan orang lain atau pasangan suami, istri, tapi bayak orang yang tersumbat dalam melakukan komunikasi tersebut. Dalam keluarga komunikasi merupakan hal yang sangat penting karena dengan komunikasi pasangan dapat mengungkapkan segala perasaanya, baik perasaan bahagia, cinta, kasih sayang, maupun perasaan tidak senang, tidak sependapat, tidak nyaman dan sebagainya.

Keempat faktor ekonomi. Ekonomi adalah salah satu syarat untuk dapat berlangsungnya kehidupan dalam rumah tangga. Meskipun tidak dapat dipungkiri bahwa harta yang banyak belum dapat menjamin kehidupan rumah tangga akan bahagia, akan tetapi tuntunan ekonomi yang berlebihan membuat pasangan suami istri menjadi retak tatkala tuntunan tersebut tidak terpenuhi.

Terkait dengan keberlangsungan pendidikan anak, perlu dipahami bahwa harmonisasi dalam keluarga merupakan dasar bagi perkembangan emosional dan psikososial anak. Kasih sayang orang tua merupakan kunci utama perkembangan sosial anak (Rakhmawati, 2015). Bagi anak sendiri ini merupakan bukti bahwa orangtua mencintai mereka. Jika orangtua sadar pentingnya komunikasi dan perhatian, tentu hal tersebut akan meminimalisir psikososial anak sebagai korban akibat keputusan orang tua yang bercerai (Mone, 2019). Komunikasi 
merupakan salah satu hal yang harus diperhatikan oleh pasangan suami istri yang sudah bercerai.

Adanya komunikasi antara orangtua dan anak setelah bercerai memperkecil pengaruh negatif dari perceraian. Kasih sayang dari keluarga kedua belah pihak dan bantuan guru dalam mengasuh anak korban perceraian membuat anak kuat dan tegar menghadapi masalah keluarganya. Hal tersebut juga dapat dilakukan dengan langkah pemulihan prestasi belajar yakni bersifat mendidik, misalnya memberikan pujian, hadiah, dan lain-lain sebagainya yang mengandung nilai edukatif (Kartono, 2005).

Pengasuhan yang dilakukan oleh orang tua pasca perceraian harus tetap berlangsung baik dengan cara tetap manjalin komunikasi dengan sang anak, hal ini terlihat pada salah satu keluarga di Desa Babakan Baru pasca bercerai mereka berkomitmen untuk membesarkan anakanak mereka bersama meski telah berpisah tempat tinggal dengan harapan rasa kasih sayang terhadap anak mereka tetap terjaga dengan baik. Hal tersebut sesuai dengan pendapat Rohner, ia mengatakan faktor yang mempengaruhi hubungan orang tua dan anak adalah pengasuhan yang dipenuhi kasih sayang dan kehangatan oleh karena itu pengasuhan orang tua yang dipenuhi kehangatan dan kasih sayang berhubungan positif dengan perkembangan anak (Ramadhani \& Krisnani, 2019). Eunjung dalam Asilah dan Hastuti menambahkan, pada keluarga yang mengalami perceraian dan memiliki tekanan yang mengakibatkan depresi dan stres baik ayah maupun ibu berpengaruh positif tehadap perilaku pengasuhan penolakan (agresi), pengabaian, dan perasaan tidak sayang (Asilah \& Hastuti, 2014).

Jika seorang ibu memperhatikan anaknya secara optimal seperti memantau kegiatan keberagamaan anak dengan baik, maka kecil kemungkinan bagi anak untuk menyeleweng. Ibu yang bekerja di rumah memiliki lebih banyak waktu untuk merawat dan mendidik anak. Sehingga anak yang sehari-harinya dalam pengawasan orang tua cenderung lebih menurut dan berperilaku baik karena orangtua merupakan role model bagi anak (Razi, Siregar, \& Zulkarnain, 2018). Dengan kata lain, perceraian tidak akan begitu berdampak bagi anak jika si anak tinggal di lingkungan yang kondusif. Artinya, jika si anak hidup di lingkungan yang sehat maka ia tidak akan mudah terpengaruh oleh lingkungan sekitar. Karena usia anak yang terbilang masih labil, maka anak akan mudah sekali terpengaruh oleh lingkungan sekitar.

Hal ini terlihat pada beberapa anak di Babakan Baru pasca perceraian yang memperoleh perlakuan berbanding terbalik dengan satu keluarga yang masih menjalin komunikasi, ayah tidak memperhatikan pendidikan anak, sedangkan ibu sibuk bekerja di tempat yang jauh dan hidup bersama neneknya. Meskipun tidak berpengaruh secara langsung bagi keberlangsungan pendidikan si anak namun hal tersebut tentu berimplikasi pada perubahan 
perilaku anak. Anak yang dulunya dikenal sebagai pribadi yang ceria berubah menjadi pemurung karena anak belum mampu menerima kenyataan pahit atas perceraian orang tuanya, selain itu anak menjadi kurang percaya diri ketika mengemukakan pendapat dan mengakibatkan anak sulit bergaul dengan orang lain, bahkan berujung pada ketidakmampuan anak dalam mengendalikan emosi.

\section{SIMPULAN}

Fenomena perceraian dan problem keberlangsungan anak yang telah dipaparkan pada hasil dan pembahasan dapat disimpulkan bahwa jika ditinjau dari aspek psikis hampir semua anak di Desa Babakan Baru mengalami kegoncangan dan belum bisa menerima kenyataan pahit dari perceraian orang tua mereka, perilaku anak berubah menjadi pemurung, tidak percaya diri dan bahkan hilang keberanian mengemukakan pendapat di depan temantemannya di sekolah. Namun dalam hal keberlangungan pendidikan anak pasca perceraian orang tua masih berjalan stabil karena hampir semua kasus perceraian di desa tersebut pengasuhan anak kembali kepada pihak ibu. Beberapa kasus anak berhenti sekolah dan atau tidak melanjutkan ke jenjang pendidikan yang lebih tinggi bukan hanya dampak dari perceraian orang tua, namun yang lebih dominan adalah faktor ekonomi dan kesadaran orang tua tentang pentingnya pendidikan bagi anak-anak mereka.

\section{DAFTAR PUSTAKA}

Abidin, Z., Nurhayati, N. F., \& Lestari, D. A. (2018). Akhlak Mulia Ditinjau Dari Pendidikan Agama Islam dalam keluarga. Prosiding Seminar Nasional Psikologi Unissula, 0(0), Article 0. http://lppm-

unissula.com/jurnal.unissula.ac.id/in dex.php/psnpu/article/view/3790

Afrida, A. (2018). Hakikat Manusia dalam Perspektif Al-Quran. Al-Qisthu: Jurnal Kajian Ilmu-Ilmu Hukum, 16(2), 54-59.

Al Yakin, A. (2016). Dampak Perceraian Orang Tua Terhadap Anak (Studi Kasus Di SMA Negeri 1 Kecamatan Nosu Kabupaten Mamasa). Pepatudzu: Media Pendidikan Dan Sosial Kemasyarakatan, 8(1), 1-13.

Asilah, A., \& Hastuti, D. (2014). Hubungan tingkat stres ibu dan pengasuhan penerimaan penolakan dengan konsep diri remaja pada keluarga bercerai. Jurnal Ilmu Keluarga $\mathcal{E}$ Konsumen, 7(1), 10-18.

Asman, A. (2019). Early Age Marriage Ditinjau Dari UU Perkawinan No. 1 Tahun 1974 Dan Analisis Konsep Hukum Islam. Jurnal Mahkamah: Kajian Ilmu Hukum Dan Hukum Islam, 4(2), 179-200.

Azmi, M. N., \& Zulkifli, M. (2018). Manusia, Akal Dan Kebahagiaan (Studi Analisis Komparatif antara AlQur'an dengan Filsafat Islam). Al Qalam: Jurnal Ilmiah Keagamaan Dan Kemasyarakatan, 127-147.

Daheri, M., \& Warsah, I. (2019). Pendidikan

Akhlak: Relasi Antara Sekolah Dengan Keluarga. At-Turats: Jurnal 
Pemikiran Pendidikan Islam, 13(2), 120.

Fikri, A. S. N. (2018). Resiliensi pada remaja yang menjadi korban perceraian orang tua [PhD Thesis]. Uin Sunan Gunung Djati Bandung.

Gazali, S. (2018). Pendidikan Anak Dalam Keluarga Perspektif Islam. Darul Ulum: Jurnal Ilmiah Keagamaan, Pendidikan Dan Kemasyarakatan, 2760.

Gumelar, G. (2017). Penampilan Guru (teacher appearance) terhadap penerimaan siswa SD di Jakarta.

Haderani, H. (2018). Tinjauan Filosofis tentang Fungsi Pendidikan dalam Hidup Manusia. Tarbiyah: Jurnal Ilmiah Kependidikan, 7(1).

Hair, M. A., \& Hair, M. A. (2018). Pendidikan Agama Islam Dalam Keluarga Dan Masyarakat. Ahsana Media, 4(2), 28-34. https://doi.org/10.31102/ahsana..4.2.2 018.28-34

Handayani, F., \& Syafliwar, S. (2017). Implementasi Mediasi dalam Penyelesaian Perkara Perceraian di Pengadilan Agama. Jurnal Al Himayah, 1(2), 227-250.

Harisah, A. (2018). Filsafat Pendidikan Islam Prinsip dan Dasar Pengembangan. Deepublish.

Hasanah, U. (2020). Pengaruh Perceraian Orangtua Bagi Psikologis Anak. Agenda: Jurnal Analisis Gender Dan Agama, 2(1), 18-24.

Helaluddin, \& Wijaya, H. (2019). Analisis Data Kualitatif: Sebuah Tinjauan Teori
E Praktik. Sekolah Tinggi Theologia Jaffray.

Kartono, M. (2005). Perbandingan perilaku agresif antara remaja yang berasal dari keluarga bercerai dengan keluarga utuh. Jurnal Psikologi Vol, 3(1), 1 .

Kusmira, D. (2018). Moderatism of Pesantren Education in Indonesia. Jurnal Ilmiah Pesantren, 4(2).

Kusumawati, T. (2016). Metode Penanaman Nilai-Nilai Agama Dan Moral Pada Pendidikan Anak Usia Dini (Paud) Al Amanah Desa Gembong Kecamatan Bojongsari Kabupaten Purbalingga Tahun Pelajaran 2013/2014 [PhD Thesis]. IAIN Purwokerto.

Lisnasari, S. F. (2017). Meningkatkan Hasil Belajar Siswa dengan Menggunakan Model Snowball Throwing pada Mata Pelajaran IPA di SD Swasta Ichwanussafa Tahun Pelajaran 2016/2017. Keguruan, 5(2).

Miles, M. B., Huberman, M. A., \& Saldana, J. (2014). Drawing and verifying conclusions. Qualitative data analysis: A methods sourcebook.

Moleong, L. J. (2010). Methodology of Qualitative Research. Bandung: Remaja Rosda Karya.

Mone, H. F. (2019). Dampak perceraian orang tua terhadap perkembangan psikososial dan prestasi belajar. Harmoni Sosial: Jurnal Pendidikan IPS, 6(2), 155-163.

Raco, J. (2018). Metode penelitian kualitatif: Jenis, karakteristik dan keunggulannya. https://doi.org/10.31219/osf.io/mfzuj 
Rakhmawati, I. (2015). Peran keluarga dalam pengasuhan anak. Jurnal Bimbingan Konseling Islam, 6(1), 1-18.

Ramadhani, P. E., \& Krisnani, H. (2019). Analisis Dampak Perceraian Orang Tua Terhadap Anak Remaja. Focus: Jurnal Pekerjaan Sosial, 2(1), 109-119.

Razi, A. D., Siregar, M., \& Zulkarnain, Z. (2018). Children Imitation on Daily Languages Family Counseling Perspective. ENLIGHTEN: Jurnal Bimbingan Konseling Islam, 1(2), 139149.

https://doi.org/10.32505/enlighten.v1i 2.774

Riadin, A., \& Fitriani, C. L. (2018). Upaya Meningkatkan Hasil Belajar Ipa Menggunakan Model Pembelajaran Kooperatif Tipe Jigsaw Dengan Berbantuan Media Alat Peraga Konkret Pada Peserta Didik Kelas V SDN-4 Kasongan Baru Tahun Pelajaran 2016/2017. Pedagogik: Jurnal Pendidikan, 13(2), 1-5.

Roulston, K. (2014). Analysing interviews. The SAGE Handbook of Qualitative Data Analysis, 297-312.

Saihu, S. (2020). Pendidikan sosial yang terkandung dalam Surat At-Taubah Ayat 71-72. Edukasi Islami: Jurnal Pendidikan Islam, 9(01), 127-148.

Suwendra, I. W. (2018). Metodologi penelitian kualitatif dalam ilmu sosial, pendidikan, kebudayaan dan keagamaan. Nilacakra.

Utami, D. D. (2018). Pembinaan Keagamaan Terhadap Anak Panti Asuhan Dharmo Yuwono Purwokerto [PhD Thesis] IAIN Purwokerto.
Wandasari, Y. (2017). Implementasi Gerakan Literasi Sekolah (GLS) Sebagai Pembentuk Pendidikan Berkarakter. JMKSP (Jurnal Manajemen, Kepemimpinan, Dan Supervisi Pendidikan), 2(2).

Warsah, I. (2017). Kesadaran Multikultural sebagai Ranah Kurikulum Pendidikan. Ta'dib: Jurnal Pendidikan Islam, 6(2), 268-279. https://doi.org/10.29313/tjpi.v6i2.2845

Warsah, I. (2018a). Interkoneksi Pemikiran Al-Ghazāli dan Sigmund Freud Tentang Potensi Manusia. Kontekstualita, 32(01), Article 01. http://e-

journal.lp2m.uinjambi.ac.id/ojp/index .php/Kontekstualita/article/view/30

Warsah, I. (2018b). Pendidikan Keimanan Sebagai Basis Kecerdasan Sosial Peserta Didik: Telaah Psikologi Islami. Psikis: Jurnal Psikologi Islami, $4(1), \quad 1-16$. https://doi.org/10.19109/psikis.v4i1.21 56

Warsah, I. (2020a). Forgiveness Viewed from Positive Psychology and Islam. Islamic Guidance and Counseling Journal, 3(2), 108-121.

Warsah, I. (2020b). Pendidikan Islam dalam Keluarga: Studi Psikologis dan Sosiologis Masyarakat Multi Agama Desa Suro Bali. Tunas Gemilang Press. 